\title{
マジックスコープ
}

東京放送 TV 制作技術部 岩西浩

本装置は，従来多く用いられてきたスクリーンプロセス技術の一つとして東京放送で開発されたも ので, 前面より背景を投射して画面合成を行なうものである. 従来のリアースクリーンプロジェクシ ヨン方式のものに比較して, 画質能率などの点で非常に優れている. そのために大型スクリーンや, カラーに拈けるスクリーンプロセスでも十分な光量を得ることが可能で, かつ占有面積が少ないため にテレビスタジオのように狭い所でも容易に利用することができる.

マジックスコープは，スクリーンプロセスの一種であ る. 従来の形式のものは，第1図に示すようにスクリー ン後方より所要の背景を投写機により投写し，スクリー ン前方の被写体と組合わせて撮影する方法である。この 方法は映画の技術として古くから用いられていて，テレ ビジョンに拉いても従来用いられてきたのであるが，そ の撮影過程，スタジオ条件などで，実際感のある合成画 面を作ることが困難であった，その原因を挙げてみると つぎのようなものが考えられる.

\section{(1) 画面の暗さ}

これは投写機の拡大率と, 光源の輝度, ランプハウス の能率などで決定される問題であるが，現在一般にテレ ビジョンスタジオで用いられているスライドの投写機の 場合, 原板の大きさは 4 インチ× 5 インチ, 光源に $3 \sim 5$

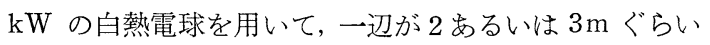
のスクリーンに投写した場合, 通常のレンズ絞り（F8〜 F5.6) では暗すぎて，一絞りも二絞りも開かなければな らない.

\section{（2）照度ムラ}

プロジェクタから投写された光線は第 2 図に示すよう に，スクリーン上に括いて投写光線の方向に強く透過さ れるので，スクリーン上の照度分布は投写機とカメラを 結ぶ線上が最も強く, 周辺に至るほど低下する.

\section{(3) 階調の変化}

スクリーン上に投写されている画面のコントラストは フィルムのコントラストに比例したものでなければなら ないが，実際は使用しているスクリーンが，透過率をよ くするために白色めるいはそれに近い色となっていて，

“「Magicscope $\rfloor$ Newly Developed Front Projection Screen-Process”. by Hiroshi Iwanishi.
スクリーン前方の 被写体を照射して いる照明光線の洩 れや反射によっ て, 照明されて投 射画面の黒の部分 が白っぽくなり， 全体としてコント ラスト・レシオが 低下したような画 面となる.これで はスクリーン前方 の被写体のコント ラストと階調が合 致しないので, 見 るからにスクリー ンに投写されてい る画面であること が歴然として，な かなか迫真感が得 られない。

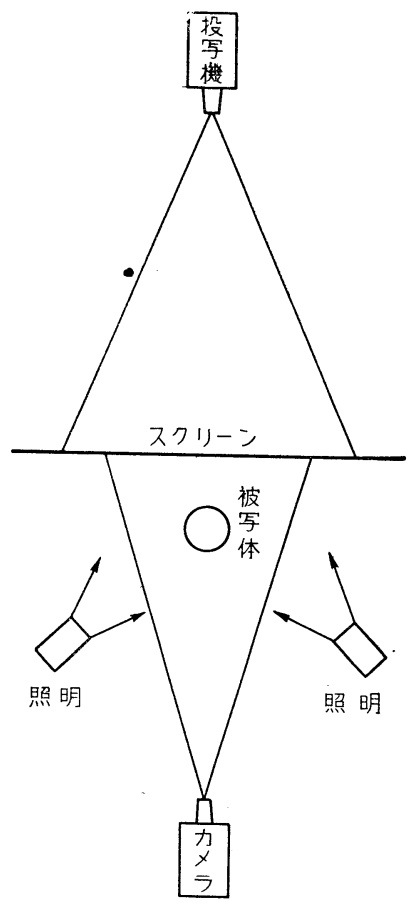

第 1 図 従来のスクリーンプロセス

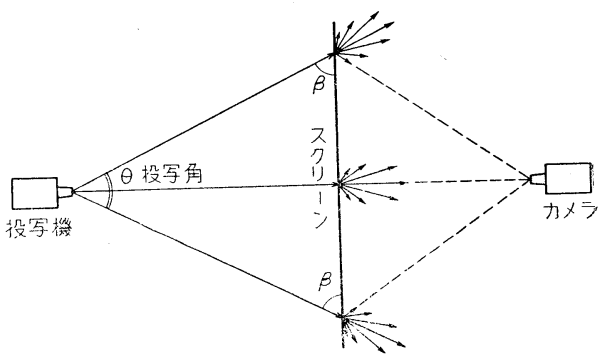

第 2 図スクリーンの照度ムラ 


\section{（4）スタジオの狭さ}

前に説明した照射ムラは第 2 図からわかるように, 投 射角 $\theta$ をなるべく小さくして, スクリーンへの投写角度 $\beta$ を直角に近いるのにするほど少なくなる。したがって 投写機とスクリーンとの距離はできるだけ離して, 長い 焦点距離のレンズで投射すればある程度防ぐことはでき る。また階調の変化はスクリーンとその前方にある被写 体との距離を離して, 被写体への照明光線がスクリーン に影響しない程度にと机ば防ぐことはできる。このため 映画に物けるスクリーンプロセスは, 細長い専用スタジ オを設けて上記の欠点防止につとめているが，テレビジ ョンスタジオのように，広さに非常に制限のあるところ では，なかなか思らようなスペースをとることはできな くて，やむを得ずお茶をにごしているのが現状である。

以上が従来の後方投写式のスクリーンプロセスに見ら れた主な欠点である。

\section{原 理 と 特 性}

マジックスコープは，以上の久点をすべて解決した前 万投写式のスクリーンプロセスである. 第 3 図はこの原 理図で, カメラと投写機はハーフミラーで組合わされて 両者のレンズの画角の中心を合致させている. ハーフミ ラーは反射率 50\%, 透過率 50\% の半透明鏡のことで, 光学的に処理された平面ガラスの上に, 薄く鏡面がスパ ッタされている. カメラと投写機のレンズの画角の中心 を合致させることは, 投写機からの投写光線によって被

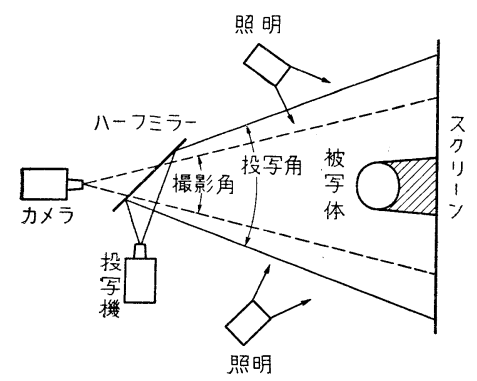

第3図 マジックス コープ原理図

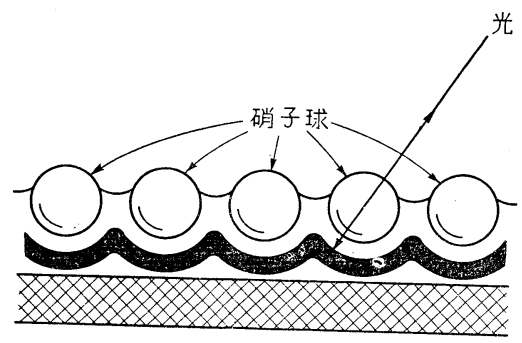

膠着刘

反射層

第4図 マジックスコープスクリーンの構造

$8(648)$
写体の影がスクリーン上隹じても, カメラからは見兑 ないようにするためと，つぎに述べる特殊スクリーンの 反射率をよくしてスクリーン能率を向上し，画面合成を 可能にするためである.

スクリーンは一般に $3 \mathrm{M}$ 社からスコッチライトという 商品名で市販されているような特殊反射材で, 上く交通 標色などに貼ってめるものと同じものである。そのスク リーン構造は第 4 図に示すように, 微小ガラス球を膠着 剤で結合させ，その裏面に反射膜を設けている，この場 合, 膠着剤を染色することにより, 種々の色のものが得 られるが, マジックスコープの場合は黒色に染めたもの を用いている.したがってスクリーンは暗灰色を呈して 怙り，反射光は白色光となる．このようなスクリーンの 反射特性は，第 5 図，第 6 図に示してある、第 5 図は入 射角の変化に対する反射率の変化を示している．点線は 標準拡散反射の炭酸マグネシウム $\left(\mathrm{MaCO}_{3}\right)$ の反射率で, 縦軸はそれとの比輝度で示してある.このカーブから， 反射率が $70 \%$ 飞低下寸る角度は 20 度であるから，20度 の 2 倍の 40 度の水平画角を有しているレンズ，すなわ ちテレビジョンのイメージオルシコンカメラでは, 焦点 距離約 $45 \mathrm{~mm}$ のレンズでも周辺光景の低下を $70 \%$ に特 さえることができる、また，反射率が白色の反射体に比 して13.5倍も岕るといらことは最も大きな特色で, この

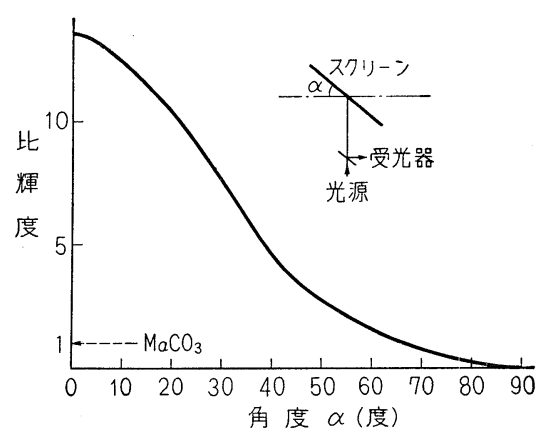

第 5 図ママジックスコープスクリーンの反射率の変化

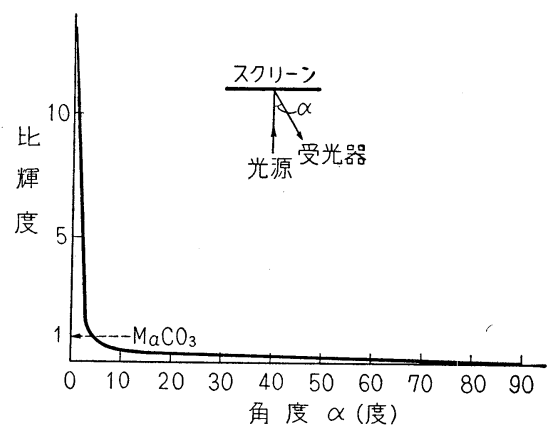

第 6 図 マジックスコープスクリーンの入射方向以外 への反射率 


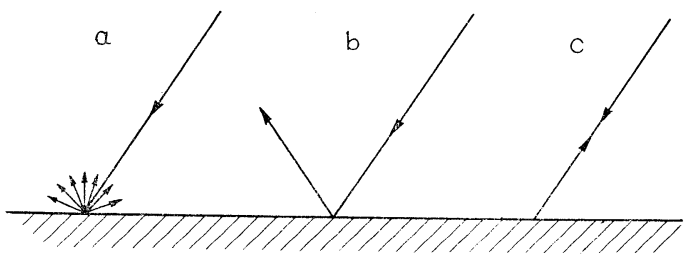

第 7 図 反射の種類

反射率の差のためにマジックスコープのプロセスのうま 味が生じている. すなわち逆に考劣ると, 投写画面の明 るさは普通の被写体に照明されている明るさの 13.5 分 の 1 でよいということで，このためにスクリーンに投写 されている画面の明るさは, スクリーン前方に位置して いる被写体に影響を与えるほどの明るさを必要としない。

これはあたかもカメラに撮影されている画面上で，ス クリーンに相当する部分のみに投写画面が投写されてい ることになり，スクリーン前方の被写体への照明を適当 にバランスをとると, 非常に良質の合成画面を得ること ができる、また同様の理由により投写機も小型低光量の もので十分であるので, 実際には数百ワットの白熱光源 のものが使用されている.たと艺゙ライドの場合は 100 ワットか 200 ワットのもの, 映画フィルムの場合は 300 ワットぐらいのクセノン放電灯を用いた映写機で女 る. 第 6 図は入射方向からはずれた角度に対する光線の 反射率を示したもので，このように入射光線は注とんど

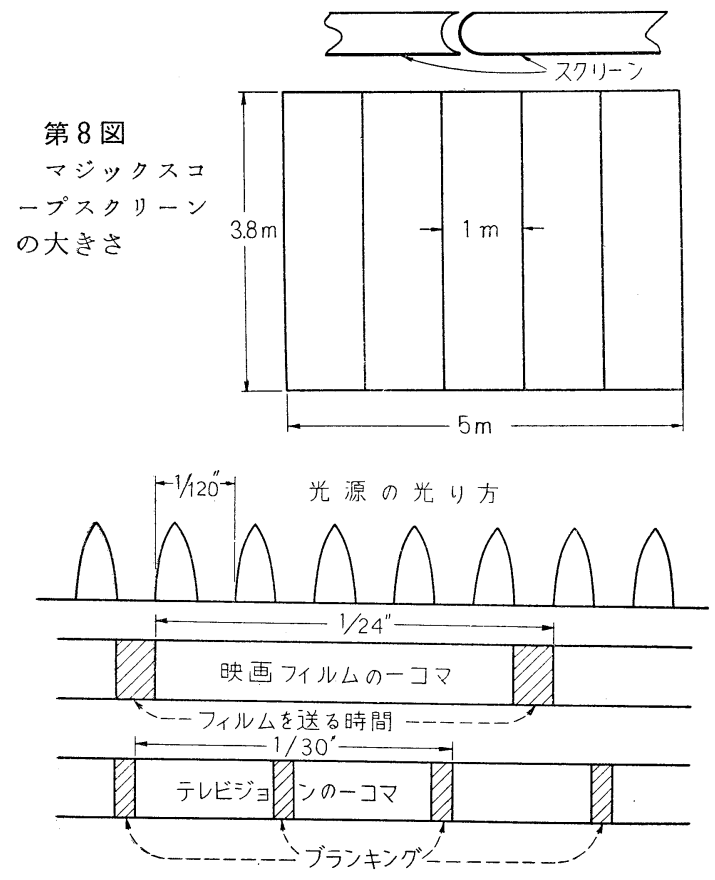

第 9 図 映画フィルム映写機の位相関係

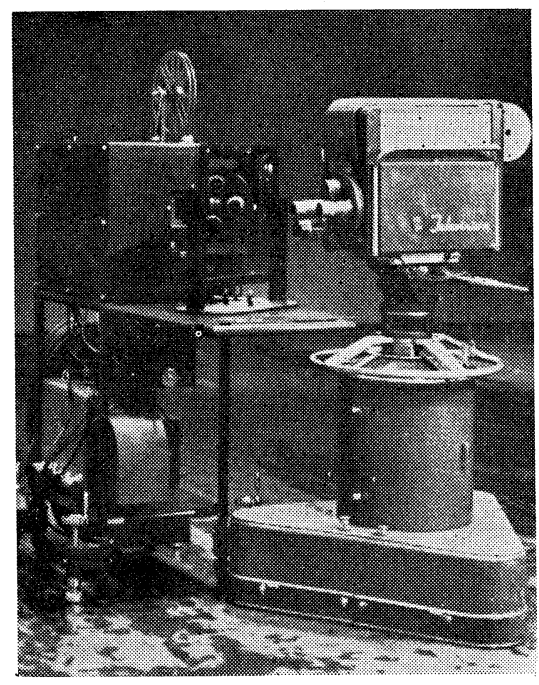

写真 1 マジックスコープフィルムプロジェクタ

入射光線に逆行して反射し, 他方向への反射光は非常に 僅かになっている.このことは第 7 図に示すよ5に，一 般の拡散反射体は $a$ に示すよ 5 に反射し鏡面のよ5な光 沢面は $b$ のよ 5 に射するのにたいし， $c$ のよ5に入射 方向に逆行するという特性をるっている. したがってス クリーンの反射率をよくするためにも, 投写機とカメラ のレンズの画角の中心を合致させることは必要でハーフ ミラーは, 前に述べた被写体の影を見えなくすることと， 二つの問題を解決する働きを有している.

スクリーンの形態は一枚のものでもよいのであるが, 東京放送では収納組立ての便をはかるため，第 8 図のよ うな構造のものとしている.一枚の大きさは，横 $1 \mathrm{~m}$, 縦 $3.8 \mathrm{~m}$ となって业り，これを必要に応じて何枚でも接 続して用いられるようになっている。 これは作業能率を 向上させ，汽車の恐のよ5に小部分の投写の際は，大さ なスクリーンを用意しなくてもすむことになる，その接 続部は第 8 図に示されているように，丸みをもった凹凹 の形とし，どの部分でもスクリーンへの入射角が 20 度 以上斜めにならないよう配慮されている. このことは第 5 図からもわかるよ5に反射率の低下は $30 \%$ 以内とな り，実際には，ほとんど接続部の判定をつけることはで きない。またスクリーンが暗灰色を呈しているというこ とはスクリーン前方による被写体への照明光線の影響が 少ないことになり，多少の洩れや反射光がスクリーンを 照射しても， ほとんど光源の方向に逆行し，投写画面の 階調をそこならことにはならない。

投写機はスライドの場合は通常市販されている家庭用 のもので十分であるし，映画フィルムの場合は，映画と テレビジョンのコマ数の違いさえ解決すれば，どのよう

(649) 9 
なものでも使用できる，極端な場合，解像度を問題にし なければ 8 ミリ映写機でも実用することができる．東京 放送では，このコマ数の違いを解決するために，クセ～ ン放電灯を用いた映写機に着目し，16 mm 映画フィル ムの映写機を開発した。クセノン放電灯を用いた映写機 は，第 9 図に示すように電源周波数の 2 倍の間歇放電が 行なわれる. したがって 60 サイクルで運転した場合, 毎秒 120 回の放電が行なわれ, フィルムは 5 回に 1 コマ 宛送られる，一方，テレビジョンの画面の方は 4 回の放 電で 1 コマとなり，コマ数の違いは 24 と 39 の最小公倍 数である 120 回の間歇放電で解決している. 写真 1 はこ の映写機とカメラとハーフミラーが，使用状態に組合わ せられた写真で，映写機は移動用ペデスタルの上に設置 され音響的障害の生じない上うにヶースに改められてい る. ハーフミラーはペデスタルに設けられている棚の上 に置かれ，角度を適当济調節して両レンズの画角の中心 を合致させるようになっている，主な仕様はつぎのと特 りである。

1. 構 成

a) $16 \mathrm{~mm}$ プロジェクター本体

b）クセノン放電灯電源

c）移動用ペデスタル

d）防音装置

e ）オートトランス

f) 附属品, 予備品, ケーブル類

2. 電 源

$\mathrm{AC} 100 \mathrm{~V} 50 \mathrm{c} / \mathrm{s}$ または $60 \mathrm{c} / \mathrm{s} 20 \mathrm{~A}$

（スクリーンプロセス用は $60 \mathrm{c} / \mathrm{s} \mathrm{C.F}$ )

3. 光 源

クセノン放電灯 $500 \mathrm{~W}$, 交流パルス点灯, 調光可 能.

4. オートトランス

$95 \mathrm{~V} \sim 12 \mathrm{~V}$ の入力電圧に対して支障なく調節運転 可能.

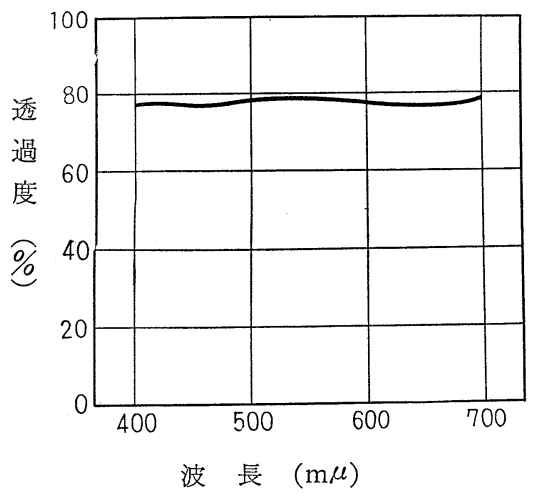

第 10 図 ハーフミラーの特性

\section{第 11 図}

マジックスコープ

の背景ワイプ

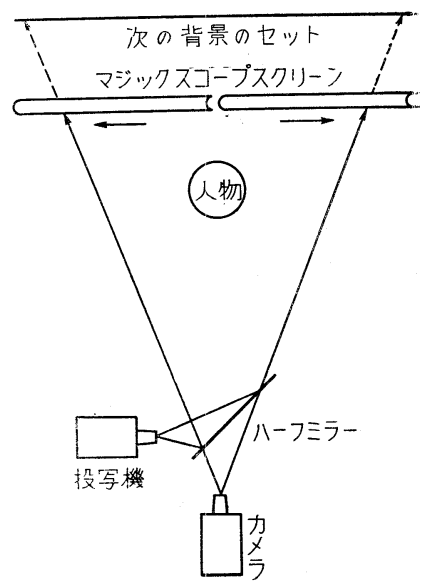

5. 映写レンズ

焦点距離 $17 \mathrm{~mm}, F 1.9$, 校りにより光量調節可能. 他皎レンズも使用可能, またアナモフィックンンズ を取りつけて，シネマスコープ版の映写も可能にな っている.

6. 映写駒数

$50 \mathrm{c} / \mathrm{s}$ の場合 25 駒, $60 \mathrm{c} / \mathrm{s}$ の場合 24 駒，ギヤー の切換による.

7. フィルム送給

正転，停止，逆転が可能なとと．

8. リール

大きさは 360 メートル（1200フィート）までとす る.

9. ペデスタル

映写機の光軸までの高さは $1,280 \mathrm{~mm}$ で, 約 50 $\mathrm{mm}$ さらに高くすることができる.

10. 防 音

本体より 1 メートルの所で 45 フォン以下

11. 音声装置

光学再生装置のみ

出カインピーダンス $600 \Omega$ 平衡型

出力レベル $+4 \mathrm{~dB},-20 \mathrm{~dB}$ 切換

12. 画ブレ

画面の 1,000 分の 1 以下（縦横両方向とも）

以上のうちスクリーンプロセス映写機として, 特に画 ブレと防音には注意を払った。

つぎにハーフミラーであるが，これが意外伤製作がむ ずかしく，特にマジックスコープに用いるものは，カメ ラのパン, ティルトが可能なように相当大きなるのが要 求され，元の上うな大面積の均一な半鏡面蒸着は非常に 困難なのであるが，種々試作の結果，満足するすのを得 ることができた。そ各色に対する反射レスポンスは第， 10図に示すように，多層膜のコーティングにより，添涪 


\section{第 12 図}

一枚のスクリー ンへ異なった背景 の投写

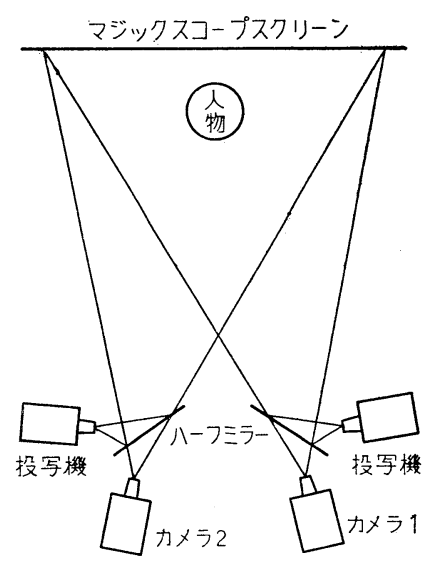

平担になって和り，カラーに和ける使用も十分支障のな いものである.

\section{使用例}

通常の後方投写方式のスクリーンプロセスとは異なっ た使用法も二, 三考光られる. 後方投写の場合は, スク リーンは主として背景となるべき画が，投写できるだけ であるが，マジックスコープの場合は前方投写のため， 自由なところに投写することができる。

\section{1. 背 景}

これは被写体後部の背景をマジックスコープで得る方 法で, 従来のスクリーンプロセスと同様な使い方である. ただしマジックスコープの場合は, 大変能率がよいので テレビジョンスタジオでは明るさの問題でなかなか困難 であった映画フィルムの投写の場合でも，十分明るい画 面が得られる. したがって従来不可能とされていた映画 のシネマスコープ版のスクリーンプロセスの場合のよう に, 大面積の背景合成には大変効果的である.

\section{2. 場面転換}

ミュージカルなどに用いて効果的な場面転換法で，第 11図に示すように，スクリーン後方に別のセットを用意

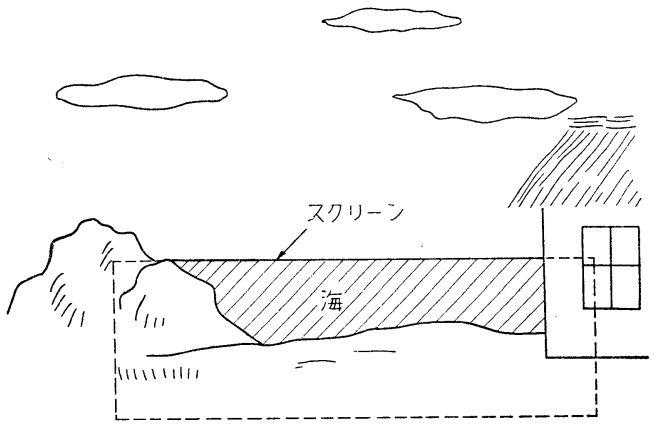

第 13 図 マシシックスコープの部分的合成
して扮き，スクリーンを中央から左右に開いたり，ある いは左右上方に移動させると, ワイプの効果で背景の及 を転換させることができる。

もら一つの場面転換法としては，第 12 図に示すよう に一枚のスクリーンに二組のマジックスコープを投写し て，カメラ 1 とカメラ 2 にそれぞれ異なった背景を合成 する方法である.これはスクリーンの特性が第 6 図に示 すように，投写機と同じ光軸にないカメラには，投写し た画面が撮影されないからである。

\section{3. 部分的合成}

例えば小道具のテレビジョンセットのスクリーンや, 魔法の鏡のよ5なものは, スクリーンや鏡の部分にマジ ックスコープのスクリーンを貼付けて, 所要の画面を投 写すれば簡単にできる. あるいは第12図に示すように海 なぞのシーンでは，海に相当する部分にスクリーンを横 にして挆き，波の映画フィルムを映写すれば大変効果的 である. 最も簡単な応用例はネオンサインで, スタジオ のセットにいらいちネオンサインを取付けては大変であ るが，スコッチテープをネオンのようにセットに貼付け てカメラのレンズの位置から弱い光源で照射すると, ネ オンサインが点灯する効果を出すことができる.

\section{4. スクリーンによる被写体のワイプ}

例觉ば第14図に示すような配置に，マジックスコープ

\section{第 14 図}

マジックスコー プスクリーンによ る被写体のワイプ
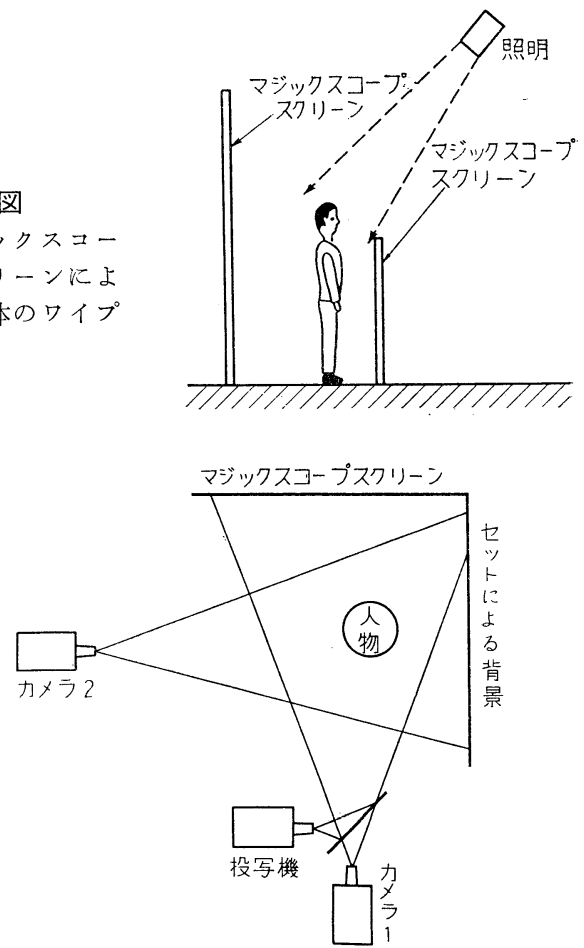

第 15 図 マ マジックスコープセットのスイッチング法 

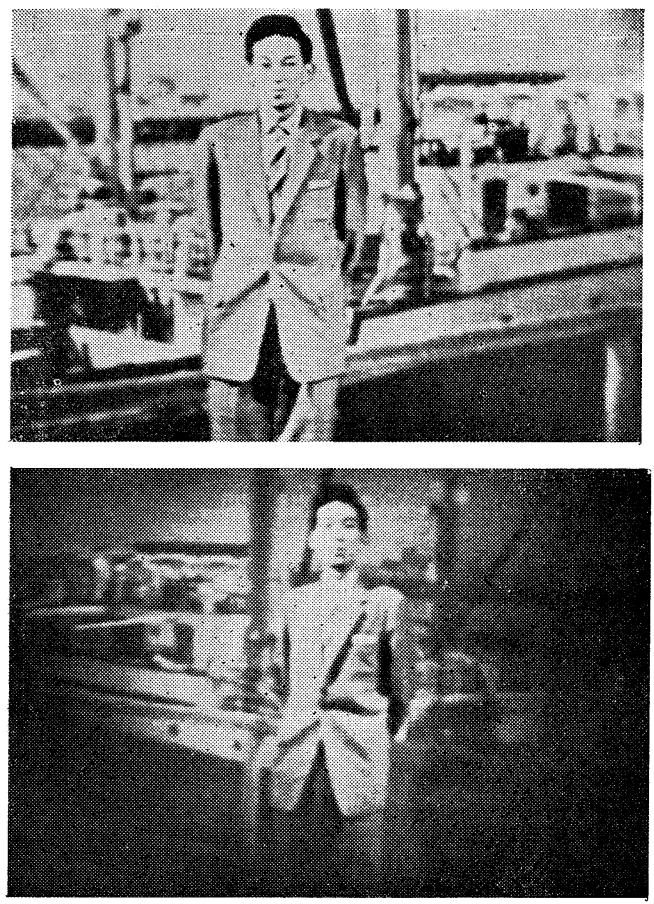

写真 2 比較写真 (上) マジックスコープ

（下）従来のスクリーンプロセス

スクリーンを置くと，投写された画面に首だけ浮んで見 える、もちろん人物が左右に動けば，首は空中をさまよ い，しゃがむと消えてしまう，同様の原理てよりしまっ ている扉のすき間から室内へ入ってしまうようなことも できる.

$$
\text { む す び }
$$

以上最も代表的な使用例を数項目挙げたが，前面投写 といら利点からは，さらになだ多くの利用法が考觉られ ると思う。

このようにマジックスクープは, 数多くの特徵を具え
第 1 表 従来のスクリーンプロセスとの比較

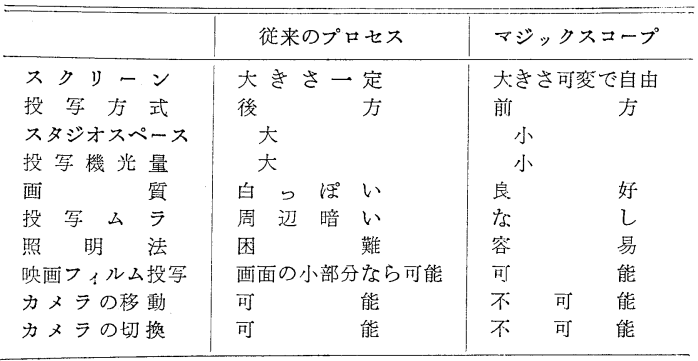

ているが，その反面欠点もある. それは映画の場合のよ うに，一台のカメラで合成撮影を行なう場合には問題は ないが，テレビジョンに沶いては，一つの被写体を数台 のカメラで撮影する場合が多い。このような場合マジッ クスコープは一台のカメラに詨し一つの合成画面のみし か得られないから，スイッチングが不可能になる。した がって他のカメラはアップショットにして背景を逃げる か，岁るい第15図に示すように，背景がセットとなる ような角度から撮影するようにしなければならない。 たカメラの移動も不可能であるので, ズームレンズによ ってその効果を代用させなければならない.

以上に述べたような得失をよくのみ込んで, マジック スコープによるスクリーンプロセスは利用すべきで, 第 1 表に示すように, 従来のスクリーンプロセスに比して 数多くの利点を有して和り, 合成画面の画質は数段と優 れている. 写真 2 はマジックスコープと, 従来のスクリ ーンプロセスとの合成画面の比較モニタ写真である.な 扣本方式は現在特許出願中である.

終りに本装置の開発に際して $16 \mathrm{~mm}$ プロジェクタに ついては北辰電機製作所，ハーフミラーについては湘南 光学の御協力を深く感謝し, 種々御指導をいただいた遠 藤常務, 吉田技術局次長を始め先輩諸氏, 研究の協力者 たる種村陽亚, 武谷雅博, 川瀬雄二, 松岡順三の諸见に 深甚なる謝意を表する.

(昭和 36 年. 7 月 25 日受付)

\section{浜松テレビが赤外線ビジコンを開発}

浜松テレビでは, 赤外線ビジコ ソの国産化を計画, 静岡大学工学 部電子工業研究所とタイアップし て 36 年度鉱工業技術試験研究補 助金の交付も受けて試作, 研究を 進めてきたが, 感度残像などの点 で外国製品に劣らない性能の赤外 線ビジコンの製造に成功した.

同ビジコンは, 感光ターゲット
(けい光面)に特殊構造をもったも ので, 感度, 残像などの面で外国 製品をはるかに上回り, 超赤外線 に対しても良く働くところから， ゲルマニウムのデイスロケーショ ソや，赤外線顕微鏡などに最適と されている。

なお, 外側形状は, 同社の可視 ビジコンと規格を一つにしている
ため, 可視ビジュンカメラへの差 替えむ自由にできるといら特徴を もっている

(日刊工業新聞)

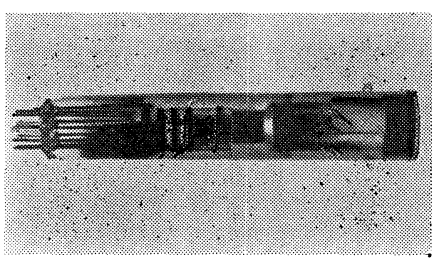

赤外線ビジニン 